\title{
Population ecology of the blue crab Callinectes danae (Crustacea: Portunidae) in a Brazilian tropical estuary
}

\author{
MARINA S.L.C. ARAÚJO ${ }^{1}$, ALINE V. BARRETO ${ }^{1}$, AURINETE O. \\ NEGROMONTE $^{1}$ and RALF SCHWAMBORN ${ }^{2}$ \\ ${ }^{1}$ Departamento de Oceanografia, Centro de Tecnologia e Geociências/ UFPE, \\ Av. da Arquitetura, s/n, Cidade Universitária, 50740-550 Recife, PE, Brasil \\ ${ }^{2}$ Departamento de Zoologia, Centro de Ciências Biológicas/UFPE, \\ Av. da Engenharia, s/n, Cidade Universitária, 50740-600 Recife, PE, Brasil
}

Manuscript received on February 2, 2011; accepted for publication on May 13, 2011

\begin{abstract}
This paper aims at describing the population ecology of the swimming crab Callinectes danae Smith, 1869 in one of the most productive estuaries of Brazil, the Santa Cruz Channel. These crabs were monthly collected from January to December/2009 at four stations along the channel, two in the upper and two in the lower estuary. A total of 2373 specimens of $C$. danae were collected during the study. Males had a larger average carapace width than non-ovigerous females $(60.0 \pm 15.6 \mathrm{~mm}$ and $52.9 \pm 12.4 \mathrm{~mm}$, respectively), an adaptation that gives greater protection for females during the copulation. Overall sex ratio did not differ significantly from 1:1. However, evaluating sex-ratio by sampling area, males and juveniles of both sexes occurred preferentially in the upper estuary $(\mathrm{p}<0.05)$, while adult females, including ovigerous, inhabited the lower estuary, an area of major marine influence $(p<0.05)$. While juveniles look for estuarine waters due to the benefit from the shelter and abundance of food, ovigerous females migrate to areas of greater depth and higher salinity in order to provide a more favorable environment for embryonic and larval development and to enhance larval dispersal. Recruitment of juveniles was continuous along the year, but intensified from March to June and, with less intensity, from October to December
\end{abstract}

Key words: Brachyura, population biology, Santa Cruz Channel, sexual dimorphism.

\section{INTRODUCTION}

The study of natural populations is essential to understand their ecological stability. In the coast of Brazil, marine and estuarine macrocrustaceans have been studied regarding some population aspects such as the distribution of individuals by size classes, density, seasonal abundance, sex ratio, age distribution, birth and mortality rates, and recruitment of juveniles (Noro and Buckup 2008).

Correspondence to: Marina de Sá Leitão Câmara de Araújo E-mail:mslc.araujo@gmail.com
The swimming crab Callinectes danae Smith, 1869 (Portunidae) is a very abundant macrocrustacean in the Brazilian estuaries, with a relevant ecological role. It is a common predator of benthic organisms (Netto and Lana 1994), feeding on macroinvertebrates such as Mollusca, Polychaeta and other Brachyura (Branco and Verani 1997), and constitutes a food resource for many aquatic organisms. This crab had its population ecology studied by some authors, such as Pita et al. (1985), Negreiros-Fransozo and Fransozo (1995), Branco 
and Masunari (2000), Chacur et al. (2000) and Baptista-Metri et al. (2005). However, these studies were only performed in the southern and southeastern Brazil. Research about this species is rare from other Brazilian coastal areas, including the northeastern littoral, where this crab has a major socio-economic importance. Except for papers published by PereiraBarros and Travas sos (1972) in Alagoas State, on its fisheries biology, and by Barreto et al. (2006) in Pernambuco State, on the size at sexual maturity of females, no information about $C$. danae is available.

This paper aims at describing the population ecology of the crab $C$. danae from a tropical estuary of the Brazilian northeast coast, as well as analyzing the spatial and seasonal fluctuation of the abundance and the ontogenetic migrations. This is a pioneer contribution to the population biology of this species in northeastern Brazil.

\section{MATERIALS AND METHODS}

The fieldwork took place at the estuarine complex of Santa Cruz Channel, Pernambuco State, northeast of Brazil. It is formed by six rivers that flow into a Ushaped channel, which separates Itamaracá Island from the continent (Fig. 1). It occupies an area of $730 \mathrm{~km}^{2}$ between the latitudes $07^{\circ} 3400000 \mathrm{~S} /$ $07^{\circ} 5501600 \mathrm{~S}$ and longitudes $34^{\circ} 0404800 \mathrm{~W} /$ $34^{\circ} 5202400 \mathrm{~W}$. The channel communicates with the Atlantic Ocean through two inlets: Catuama inlet in the North and Orange inlet in the South (Macedo and Koening 1987). The region has a climate within the As' type of Koeppen system, i.e. hot and humid with rainy autumn and winter. It shows a dry season during the austral summer, between the months of September and February, and a rainy season from March to August (Cavalcanti and Kempf 1970).

Four sampling stations were established along the Santa Cruz Channel (Fig. 1): 1 - Congo River mouth $\left(7^{\circ} 4602600 \mathrm{~S} / 34^{\circ} 5302700 \mathrm{~W}\right) ; 2$ - President Vargas bridge $\left(7^{\circ} 4602800 \mathrm{~S} / 34 \circ 5301300 \mathrm{~W}\right) ; 3$ Paripe River mouth $\left(7^{\circ} 4803800 \mathrm{~S} / 34^{\circ} 5102700 \mathrm{~W}\right)$; and 4 - Coroa do Avião sand bank ( $7^{\circ} 4805900 \mathrm{~S} /$ $\left.34^{\circ} 5002800 \mathrm{~W}\right)$. For the purpose of this work, the first two sampling stations were considered the upper estuary, while the last two ones the lower estuary.

The upper estuary presents muddy substratum dominated by fine sand (Paiva et al. 2005), resulting from the slow water currents at this area. The mangrove forest occupies large areas, and during the low tide mud flats are exposed and the depths are lower than $2 \mathrm{~m}$ (Macedo et al. 2000).

At the lower estuary, Paripe River, the only one that springs from the Island, flows into the channel near the south inlet. It presents muddy sand substratum and the marine influence is remarkable along almost its whole extension (Silva and Koening 1993). At the south inlet, the Coroa do Avião sand bank is formed by the deposition of sediments brought by the longshore drift (Silva et al. 2007). The depths at the area vary from 10 to $17 \mathrm{~m}$ (Eskinazi-Leça et al. 1980).

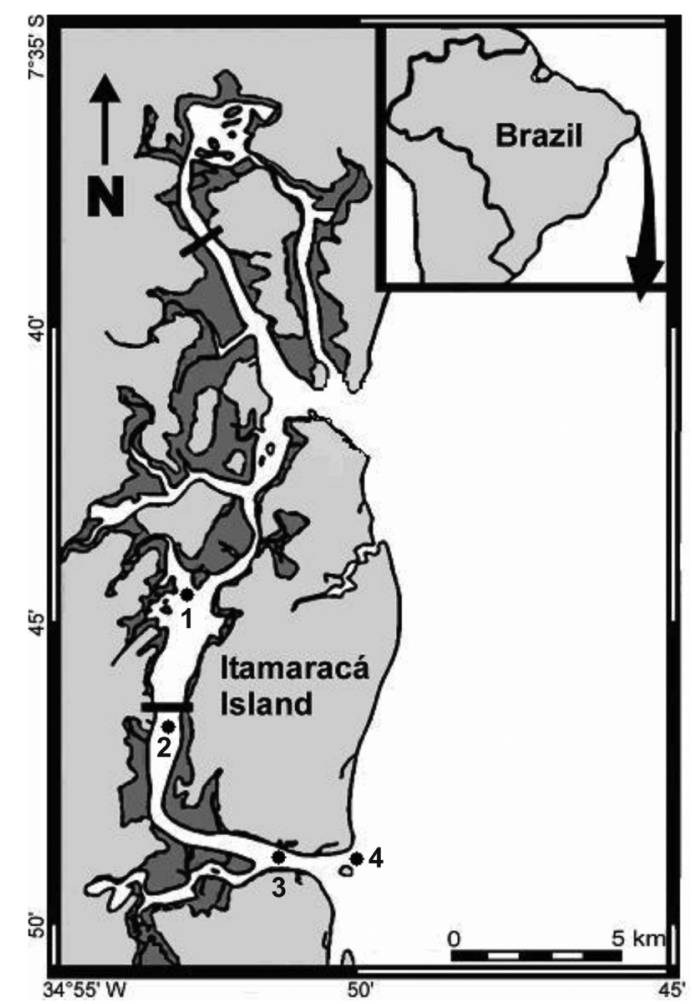

Fig. 1 - Santa Cruz Channel (SCC), with sampling stations indicated by numbers: 1 = Congo River mouth; 2 = President Vargas bridge 3 = Paripe River mouth; and 4 = Coroa do Avião sand bank. 
Monthly, samples were collected from January to December 2009 on full moon days; sampling started during ebb tide and ended during flood tide. Portunid crabs were collected with a dipnet and attracted with anchovie baits (Engraulidae). In each monthly fieldwork, the following abiotic variables were also obtained: water temperature and water samples for later analyses of salinity, $\mathrm{pH}$ and dissolved oxygen concentration (D.O.).

In the laboratory, the specimens were identified, sexed and classified as juveniles and adults by the morphology of the abdomen. Carapace width (CW) of each individual was measured using a $0.05 \mathrm{~mm}$ precision caliper, excluding lateral spines.

The analysis of abiotic variables was performed following the methods described by Strickland and Parsons (1960): the Winkler method for D.O. and the Mohr-Knudsen method for salinity. The $\mathrm{pH}$ values were obtained with a bench $\mathrm{pH}$ meter. Oxygen saturation (\%) was calculated based on the values of D.O., salinity and temperature, using the equations of the International Oceanographic Tables (UNESCO 1973).

All statistical analysis were performed at $\alpha=0.05$. The minimum, mean \pm standard deviation and maximum values of each abiotic variable were estimated. Student $t$ test was used to compare abiotic variables between dry and rainy periods, and between upper and lower estuary. The minimum, mean \pm standard deviation and maximum values of CW and CPUE (catch per unit effort, as the number of crabs captured per hour) were estimated. Student $t$ test was used to compare CPUE between dry and rainy periods, and $\mathrm{CW}$ between males and females. Kruskal-Wallis nonparametric test was used to compare CPUE and relative abundance of juvenile females, adult females, juvenile males and adult males between upper and lower estuary, followed by Dunn's a posteriori test when significant differences were found.

The sex ratio and relative abundance of juveniles and adults were analyzed summing up all samples collected in the whole studied period and by the discrimination of upper and lower estuary and by months. The $\chi^{2}$ test was applied to verify whether sex ratio deviates significantly from 1:1 (Mendelian proportion). The recruitment was estimated through a multinomial proportion analysis (MANAP), which was applied to compare the relative abundance of juveniles and adults by month.

To characterize the population structure, the animals were grouped into $\mathrm{CW}$ classes with an amplitude of $5 \mathrm{~mm} . \chi^{2}$ tests were applied to check for the equality of sex ratios for each class. Size classes were plotted for males and females separately. The mode was estimated from the midpoint of the range shift. The Shapiro-Wilk test was used to test the normality of frequency distributions that was classified by the number of modes in: unimodal, bimodal and polymodal.

Pearson's coefficient of linear correlation $(r)$ was used to assess the correlation between the CPUE, number of juvenile and adult males and females with abiotic variables by periods (dry and rainy).

\section{RESULTS}

The data of abiotic variables are presented in Table I. Mean water temperature was $29.3 \pm$ $1.4^{\circ} \mathrm{C}$ (ranging from $26.5^{\circ} \mathrm{C}$ in July to $31^{\circ} \mathrm{C}$ in November), mean salinity was $27.8 \pm 4.7$ (from 16.2 in July to 33.5 in December), mean $\mathrm{pH}$ was $8.1 \pm$ 0.2 (from 7.8 in July to 8.6 in May) and mean D.O. was $4.4 \pm 0.7 \mathrm{ml} . \mathrm{L}^{-1}$ (from $3.5 \mathrm{ml} . \mathrm{L}^{-1}$ in April to $5.8 \mathrm{ml} . \mathrm{L}^{-} 1$ in December). Mean oxygen saturation was $106.6 \pm 21.9 \%$, ranging from saturated $(83.2 \%)$ in February to supersaturated (161.6\%) in October.

Although the values of each abiotic variable have fluctuated during the sampling year, no significant differences were observed in the mean values between rainy and dry periods for temperature $(\mathrm{t}=1.82 ; p=0.07), \mathrm{pH}(\mathrm{t}=1.41 ; p=0.16)$, D.O. $(\mathrm{t}=0.18 ; p=0.85)$ and oxygen saturation $(\mathrm{t}=0.35 ; p=0.09)$. Salinity was the only factor that 
TABLE I

Mean monthly values of each abiotic variable at Santa Cruz Channel. Temp $=$ temperature; Sal = salinity; D.O. = dissolved oxygen; \%Sat D.O. = dissolved oxygen saturation.

\begin{tabular}{|c|c|c|c|c|c|}
\hline \multirow{2}{*}{ Months } & \multicolumn{5}{|c|}{ Rainy period } \\
\hline & Temp & Sal & $\mathrm{pH}$ & D.O. & \% Sat D.O. \\
\hline Mar & 30.5 & 29.2 & 8.0 & 4.2 & 95.6 \\
\hline Apr & 30.4 & 27.3 & 7.9 & 3.8 & 92.9 \\
\hline May & 30.3 & 26.1 & 8.6 & 4.3 & 126.6 \\
\hline Jun & 28.5 & 23.4 & 8.0 & 4.4 & 102.2 \\
\hline Jul & 26.5 & 16.2 & 7.8 & 5.3 & 92.1 \\
\hline Aug & 27.0 & 26.3 & 8.0 & 3.9 & 116.6 \\
\hline Mean \pm sd & $28.9 \pm 1.8$ & $24.8 \pm 4.6$ & $8.1 \pm 0.3$ & $4.3 \pm 0.5$ & $104.3 \pm 13.0$ \\
\hline \multirow{2}{*}{ Months } & \multicolumn{5}{|c|}{ Dry period } \\
\hline & Temp & Sal & $\mathrm{pH}$ & D.O. & \% Sat D.O. \\
\hline Jan & 29.3 & 32.1 & 8.4 & 4.8 & 84.2 \\
\hline Feb & 30.0 & 29.8 & 8.1 & 3.5 & 83.2 \\
\hline Sep & 28.5 & 27.6 & 8.1 & 3.8 & 102.3 \\
\hline Oct & 29.3 & 30.6 & 8.1 & 4.2 & 161.6 \\
\hline Nov & 31.0 & 31.9 & 8.3 & 4.9 & 104.4 \\
\hline Dec & 30.5 & 33.5 & 8.3 & 5.8 & 117.8 \\
\hline Mean \pm sd & $29.8 \pm 0.9$ & $30.9 \pm 2.1$ & $8.2 \pm 0.1$ & $4.5 \pm 0.8$ & $108.9 \pm 26.4$ \\
\hline
\end{tabular}

varied significantly between rainy and dry periods $(t=5.41 ; p<0.05)$. On the other hand, no abiotic variables showed significant differences between upper and lower estuary $(\mathrm{p}>0.05)$. However, the mean salinity found in the lower estuary was higher (29.5) than in the upper estuary (26.5).

A total of 2373 specimens of $C$. danae were sampled during the study period, among those, 1210 males and 1163 females. The overall sex ratiowas 1:0.96 ( $\delta^{\lambda}:$ 우), and it did not differ from the expected $1: 1$ proportion $\left(\chi^{2}=0.9 ; p>0.05\right)$. However, juveniles were significantly more abundant than adults $\left(\chi^{2}=483.4 ; p<0.05\right)$, totaling $72.5 \%$ of the population (Table II).
Significant differences $(p<0.05)$ were observed in the sex ratio of the sampling areas (Fig. 2); males outnumbered females in the upper estuary, while females outnumbered males in the lower estuary. However, juvenile males outnumbered adult ones both in the upper and in the lower estuaries. Juvenile females outnumbered adult ones in the upper estuary, while adult females outnumbered juvenile females in the lower estuary. In addition, ovigerous females were only found in the lower estuary.

Monthly sex ratio did not differ from the Mendelian proportion, except in February, when males were significantly more abundant than females $\left(\chi^{2}=5.8 ; p<0.05\right)$. Juveniles were more abundant 
TABLE II

Callinectes danae. Absolute and relative abundances (\%) of each sex and age groups at Santa Cruz Channel.

\begin{tabular}{c|c|c|c|c|c|c|c|c}
\hline Sex Age & \multicolumn{4}{|c|}{ Absolute abundance } & \multicolumn{4}{c}{ Relative abundance (\%) } \\
\hline & Juveniles & Adults & Ovigerous & Total & Juveniles & Adults & Ovigerous & Total \\
\hline Males & 933 & 277 & - & $\mathbf{1 2 1 0}$ & 39.3 & 11.7 & - & $\mathbf{5 1}$ \\
Females & 789 & 351 & 23 & $\mathbf{1 1 6 3}$ & 33.2 & 14.3 & 1.5 & $\mathbf{4 9}$ \\
Total & $\mathbf{1 7 2 2}$ & $\mathbf{6 2 8}$ & $\mathbf{2 3}$ & $\mathbf{2 3 7 3}$ & $\mathbf{7 2 . 5}$ & $\mathbf{2 6 . 0}$ & $\mathbf{1 . 5}$ & $\mathbf{1 0 0}$ \\
\hline
\end{tabular}

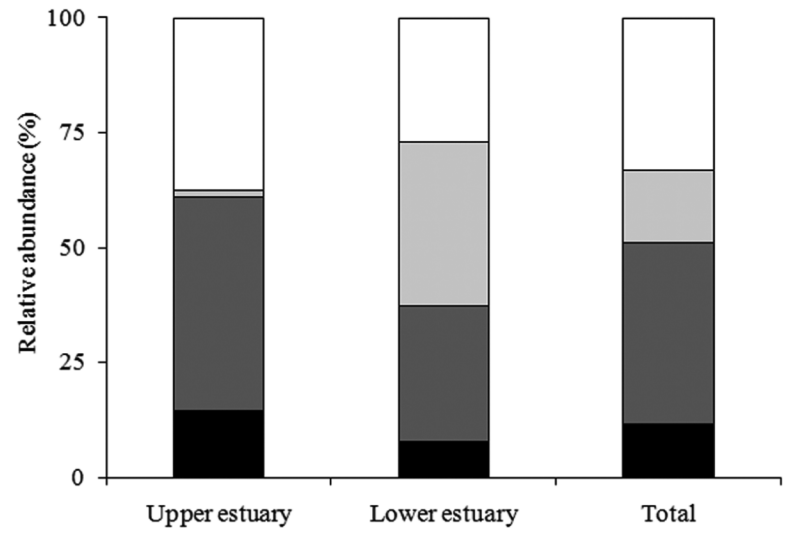

Fig. 2 - Callinectes danae. Relative abundance of adults and juveniles of both sexes, in the upper and lower estuaries at the Santa Cruz Channel. The total number obtained in these sites is also presented.

than adults in most months, except in August and September when no significant differences could be noticed $\left(\chi^{2}=0.1\right.$ and 1.3 , respectively; $\left.p>0.05\right)$ (Fig. 3). The recruitment of juveniles to the population is continuous, but intensified from March to June and, less intense, from October to December.

The mean CW of males was $60.0 \pm 15.6 \mathrm{~mm}$ (ranging from 23.6 to $95.6 \mathrm{~mm}$ ), that of nonovigerous females was $52.9 \pm 12.4 \mathrm{~mm}$ (from 25.0 to $82.3 \mathrm{~mm}$ ) and that ovigerous females was 64.8 $\pm 5.2 \mathrm{~mm}$ (from 50.5 to $72.0 \mathrm{~mm}$ ). Males were significantly larger than non-ovigerous females $(\mathrm{t}=9.48 ; p<0.05)$, while ovigerous females were significantly larger than males $(\mathrm{t}=-3.61 ; p<0.05)$ and non-ovigerous females $(\mathrm{t}=-8.14 ; p<0.05)$.

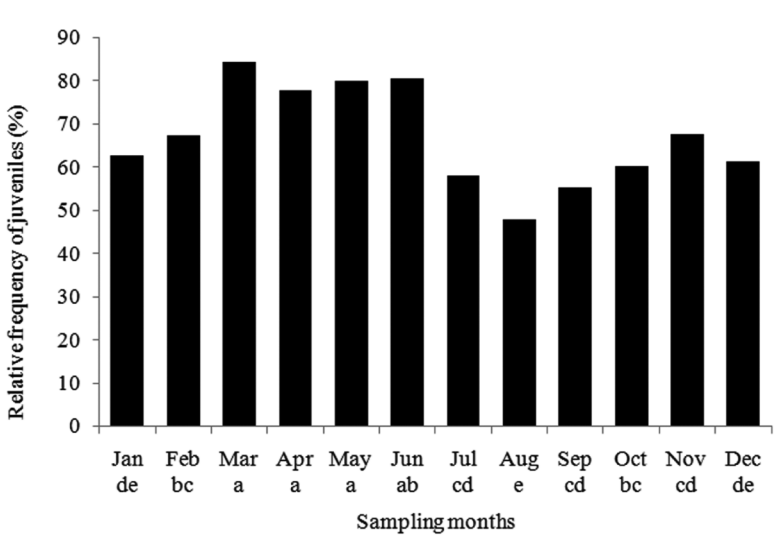

Fig. 3 - Callinectes danae. Temporal distribution of juveniles frequency at the Santa Cruz Channel. Note: months sharing at least one letter in common did not differ significantly among them $(\alpha=0.05)$.

The swimming crabs were distributed into sixteen CW classes, ranging from 20.0 to $100.0 \mathrm{~mm}$ $\mathrm{CW}$ (Fig. 4). Females were distributed in a smaller amplitude $(27.5 \mid-82.5 \mathrm{~mm})$ than males $(22.5 \mid-$ $97.5 \mathrm{~mm})$. There were significant differences in the proportion of males and females by size class, with males being dominant in all four classes from 75.0 to $95.0 \mathrm{~mm}(\mathrm{p}<0.05)$. Females were dominant in the classes of $25.0 \mid-30.0$ and $35.0 \mid-40.0 \mathrm{~mm}(p<0.05)$. The distribution by size class for both sexes tends to bimodality $(p<0.05)$. However, one characteristic mode for each sex can be detected (Fig. 4): $52.5 \mathrm{~mm}$ for males and $47.5 \mathrm{~mm}$ for females.

Mean CPUE was $64.6 \pm 51.0$ ind. $\mathrm{h}^{-1}$, ranging from 9.8 ind. $\mathrm{h}^{-1}$ in March to 225.0 ind. $\mathrm{h}^{-1}$ in 


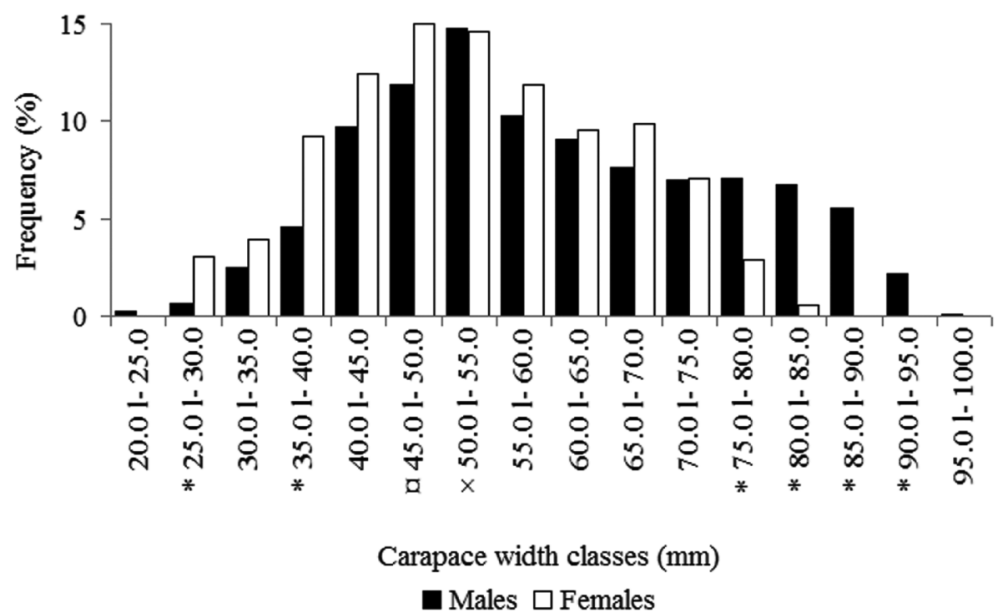

Fig. 4 -Callinectes danae. Frequency distribution of males and females into CW size classes at the Santa Cruz Channel. = significant differences $(\alpha=0.05)$; $\alpha=$ mode of females; $\times=$ mode of males.

\section{TABLE III}

Callinectes danae. Minimum, mean and maximum values of catch per unit effort (CPUE = \# of individuals per hour) by sampling area and collection period at the Santa Cruz Channel.

\begin{tabular}{cc|c|c|c}
\hline \multirow{2}{*}{\multicolumn{2}{c|}{ Sources of variation }} & \multicolumn{3}{c}{ CPUE (ind. $\mathrm{h}^{-1}$ ) } \\
\cline { 3 - 5 } & Upper estuary & 11.6 & Mean $\pm \mathrm{sd}$ & Max. \\
\hline \multirow{2}{*}{ Sampling } & Lower estuary & 9.8 & $33.5 \pm 20.2$ & 87.1 \\
area & Dry & 11.6 & $40.9 \pm 51.1$ & 225.0 \\
\multirow{2}{*}{ Period } & Rainy & 9.8 & $57.9 \pm 50.0$ & 182.0 \\
& & & & 225.0 \\
\hline
\end{tabular}

February. The CPUE in the upper estuary was significantly higher than in the lower estuary $(p<$ 0.05 ). No significant differences were found between dry and rainy periods $(\mathrm{t}=-0.78 ; p=0.44)$ (Table III).

No significant correlation between abiotic variables and CPUE was observed $(p>0.05)$. However, when analyzing separately dry and rainy periods, a significant influence of the D.O. was observed in the rainy period $(\mathrm{r}=0.75 ; p=0.01)$.

After separating sex and age groups, some other significant correlations could be noticed: the oscillation of the number of juvenile females was positively correlated with the variation of the temperature $(r=0.81)$, while the number of adult females was negatively correlated with temperature, salinity and $\mathrm{pH}(\mathrm{r}=-0.74,-0.75$ and -0.69 , respectively), for both dry and rainy periods. The oscillation of the number of juvenile males was negatively correlated to that of dissolved oxygen during the dry period $(\mathrm{r}=-0.82)$, and positively correlated to that of temperature during the rainy period $(r=0.83)$. 


\section{DISCUSSION}

Studies conducted at Santa Cruz Channel have demonstrated that this environment can be regarded as a coastal water body under terrigenous influence, because several rivers flow into it (Cavalcanti et al. 1981). No physicalchemical variable assessed in the present study varied significantly among the sampling stations, a feature that may be due to the tidal effect and to the non-simultaneous collection of samples. However, the mean salinity was higher in the lower estuary, showing that this area has saltier water and greater marine influence. Although oscillations in abiotic variables have been observed throughout the year, salinity was the only one that varied significantly between dry and rainy periods; this is a result of a considerable increase in the runoff during rainy months. Seasonal variations of salinity in the region have been plenty evidenced previously (Macedo et al. 1973).

Due to the complexity of the marine habitat, the distribution of many species can vary according to theirstage of development. The blue crab Callinectes sapidus presents sexual and ontogenetic differences in the movement across the estuary, causing habitat partitioning between sexes and ages (Hines et al. 1987). Other studies have also suggested habitat partitioning for portunids (Negreiros-Fransozo and Nakagaki 1998). However, this ecological aspect still remains poorly described for tropical and subtropical zones. Regarding the spatial distribution of $C$. danae at Santa Cruz Channel, a sex-specific spatial segregation was revealed, causing a habitat partitioning. Males and juveniles of both sexes preferentially reside in the upper estuary, while adult females, including the ovigerous, dominate in the lower estuary, which is the area of stronger marine influence. Such pattern seems to be a characteristic of $C$. danae, as it has been shown by several authors, such as Pita et al. (1985) and Chacur et al. (2000) in Southwestern Brazil, and Branco and Masunari (2000) in Southern Brazil. Furthermore, Pereira-
Barros and Travassos (1972) have suggested a reproductive migration of females of $C$. danae at Mundaú Lagoon, state of Alagoas, Northeastern Brazil, based on the absence of females inside the lagoon in most months. However, as these latter authors obtained samples from debarkment areas of the canoes that fished throughout the whole lagoon, this information is controversial. Thus, the present paper brings new light to the migration phenomenon for the northeastern coast of Brazil.

As cited by Buchanan and Stoner (1988), this pattern of distribution of swimming crabs is the result of a combination between habitat preferences and intra/ interspecific interactions. In the present study, an ontogenetic migration of $C$. danae can be proposed. The juvenile crabs migrate to estuarine areas, where they are protected from predation pressure that is usually higher in open seas and additionally the abundance of shelter and food is available in this environment, as suggested by Hines et al. (1987) and Guerin and Stickle (1997). After development, adult and ovigerous females migrate to the lower estuary and the open sea. These areas of greater depth and salinity are propitious to embryonic and larval development, as recorded for other portunids such as C. sapidus by Williams (1974), C. similis by Hsueh et al. (1993) and C. ornatus by Negreiros-Fransozo and Fransozo (1995).

Sexual dimorphism in the carapace width of $C$. danae, being males larger than females, is largely known (Williams 1974, Baptista-Metri et al. 2005). The larger size of males is supposed to be an adaptation that performs protection to females throughout the timeconsuming copulatory embrace and immediately after copulation, as has been reported for portunids such as $C$. ornatus by Mantelatto and Fransozo (1996) and A. cribrarius by Pinheiro and Fransozo (1998). This sexual difference in size arises at the puberty molt, when metabolic energy is intended for somatic growth in males, while in females, it is distributed between egg production and growth (Hartnoll 1985). 
The unimodal distribution of size frequency usually reflects a continuous recruitment, as has been reported for C. ornatus by Mantelatto (1995). On the other hand, bimodality may indicate differential migration of demographic categories, as observed in the present study, and/or recruitment through pulses (Díaz and Conde 1989). At the Santa Cruz Channel, the recruitment of juveniles into the population of $C$. danae occurs year-round, but it is enhanced from March to June and from October to December, probably as a result of the seasonal intensity in the reproduction of the species.

The Brazilian federal legislation that deals with swimming crabs fisheries established in 1983 (ordinance \# N-24/83) allows only to fish $C$. danae bigger than $120.0 \mathrm{~mm} \mathrm{CW}$, in inland waters. This value is far above the mean CW found in this study; actually, it is nearly twice the size (males $-60.0 \mathrm{~mm}$; non-ovigerous females $-52.9 \mathrm{~mm}$, and ovigerous females $-64.8 \mathrm{~mm}$ ). It is also much higher than those averages found by other authors, as Baptista-Metri et al. (2005) at Shangri- Lá Beach, state of Paraná (males $-66.7 \mathrm{~mm}$; females $-61.0 \mathrm{~mm}$ ). These studies show how this ordinance is outdated and inaccurate. Further studies about the reproductive pattern of C. danae are highly desirable in order to establish the correct size of this swimming crab for secure fishing.

In the present study, all evaluated abiotic variables exerted some influence in the abundance of $C$. danae. Chacur et al. (2000) concluded that salinity is the most important factor to explain the distribution of $C$. danae. On the other hand, Buchanan and Stoner (1988) argued that temperature is the most important factor affecting the temporal abundance of this species. Although it is possible to isolate each environmental variable and to consider the influence of each one separately, the behavior of an individual at a certain time will be determined not only by an exogenous factor, but by the influence and interaction of many variables in synergistic action and by endogenous factors (Soares-Gomes and Figueiredo 2002).

\section{CONCLUSION}

An ontogenetic and sex-specific migration of the swimming crab Callinectes danae in a tropical Brazilian estuary is suggested. Males, ovigerous and non-ovigerous females, as well as juveniles and adults, showed a clear spatial segregation within the estuary.

The present paper is an important contribution to the knowledge on the ecology of this species on the northeast Brazilian coast. Still, more studies in this region are necessary, due to its ecological and socioeconomic importance.

\section{ACKNOWLEDGMENTS}

This paper is part of a master degree dissertation on Oceanography improved by the first author. We are sincerely thankful to all laboratory members who helped us during the sampling and the laboratory activities. We also wish to thank Dr. Luis Ernesto Arruda Bezerra (UFC/UFPE) and Dr. Monica Ferreira da Costa (UFPE) for the important revision of the text, M.Sc. Maria Elisa Pitanga and M.Sc. Keyla Travassos (UFPE) for the chemical analysis, and Dr. Daniela da Silva Castiglioni (UFSM), Dr. Petrônio Alves Coelho (UFPE/UFAL) and Dr. Tereza Cristina dos Santos Calado (UFAL) for important suggestions performed during the dissertation analysis, which were very useful for the elaboration of this article.

\section{RESUMO}

O presente trabalho tem por objetivo descrever a estrutura populacional do siri Callinectes danae Smith, 1869 em um dos estuários mais produtivos do Brasil, o Canal de Santa Cruz. As coletas foram realizadas mensalmente de Janeiro a Dezembro/ 2009 em quatro estações ao longo do canal, duas no estuário superior e duas no estuário inferior. Um total de 2373 exemplares de C. danae foi coletado. Os machos apresentaram média de largura de carapaça superior à das fêmeas não-ovígeras $(60,0 \pm 15,6 \mathrm{~mm}$ e $5,9 \pm 12,4 \mathrm{~mm}$, respectivamente), 
uma adaptação que confere maior proteção às fêmeas durante a cópula. A proporção sexual total não diferiu significativamente de 1:1. Porém, avaliando a 'sex-ratio' por área de coleta, os machos e os juvenis residem preferencialmente no estuário superior $(p<0,05)$, enquanto as fêmeas adultas e ovígeras habitam no estuário inferior, área de maior influência marinha $(p<0,05)$. Enquanto os juvenis procuram águas estuarinas devido a abundância de abrigos e comida, as fêmeas ovígeras migram para áreas de maior profundidade e maior salinidade visando prover um ambiente mais favorável ao desenvolvimento embrionário e larval, além de favorecer a dispersão da prole. O recrutamento de juvenis foi contínuo ao longo do ano, mas intensificado entre Março e Junho, e em menor intensidade, de Outubro a Dezembro.

Palavras-chave: Brachyura, biologia populacional, Canal de Santa Cruz, dimorfismo sexual.

\section{REFERENCES}

Baptista-Metri C, Pinheiro MAA, Blankensteyn A AND BORZONE CA. 2005. Biologia populacional e reprodutiva de Callinectes danae Smith (Crustacea: Portunidae), no Balneário Shangri-lá, Pontal do Paraná (PR), Brasil. Rev Bras Zool 22: 446-453.

BARreto AV, BATISTA-Leite LMA AND AgUiAR MCA. 2006. Maturidade sexual das fêmeas de Callinectes danae (Crustacea, Decapoda, Portunidae) nos estuários dos rios Botafogo e Carrapicho, Itamaracá-PE Brasil. Iher Ser Zool 96: 141-146.

BRANCO JO AND MASUNARI S. 2000. Reproductive ecology of the blue crab Callinectes danae Smith, 1869 in the Conceição Lagoon system, Santa Catarina Isle, Brazil. Rev Bras Zool 60: 17-27.

BRANCO JO AND VERANI JR. 1997. Dinâmica da alimentação natural de Callinectes danae Smith (Decapoda, Portunidae) na Lagoa da Conceição, Florianópolis, Santa Catarina, Brasil. Rev Bras Zool 14: 1003-1018.

BUCHANAN BA AND STONER AW. 1988. Distributional patterns of blue crabs (Callinectes spp.) in a tropical estuarine lagoon. Estuaries 11: 231-239.

CAVAlCANTI LB AND KEMPF M. 1970. Estudo da plataforma continental na área do Recife (Brasil): II Meteorologia e Hidrologia. Trab Oceanogr Univ Fed PE 9: 149-158.

Cavalcanti LB, Macedo SJ And Passavante JZO. 1981. Estudo ecológico da região de Itamaracá, PernambucoBrasil. XXI. Caracterização do Canal de Santa Cruz em função dos parâmetros físico-químicos e pigmentos fotossintéticos. Trab Oceanogr Univ Fed PE 16: 157-216.
Chacur MM, Mansur CB AND Negreiros-Fransozo ML. 2000. Distributional patterns, seasonal abundance and moult cycle of Callinectes danae Smith, 1869 in the Ubatuba region, Brazil. Nauplius 8: 215-226.

DíAZ H AND CONDE JE. 1989. Population dynamics and life of mangrove crab Aratus pisonii (Brachyura, Grapsidae) in a marine enviroment. Bull Mar Sci 45: 148-163.

EskinaZI-LeÇA E, MacÊdo SJ AND PASSAVAnte JZO. 1980. Estudo ecológico da região de Itamaracá, Pernambuco, Brasil. V. Composição e distribuição do microfitoplâncton na região do Canal de Santa Cruz. Trab Oceanogr Univ Fed PE 15: 185-262.

GUERIN JLAND STICKLE WB. 1997. Effects of salinity on survival and bioenergetics of juvenile smaller blue crabs, Callinectes similis. Mar Biol 129: 63-69.

HARTNOLLRG. 1985. Growth, sexual maturity and reproductive output. In: WENNER AM (Ed), Factors in adult growth, Rotterdam: AA Balkema, Netherlands, p. 15-17.

HINES AH, LIPCIUS RN AND HADDON AM. 1987. Population dynamics and habitat partitioning by size, sex and molt stage of blue crabs Callinectes sapidus in a subestuary of Central Chesapeake Bay. Mar Ecol Prog Ser 36: 55-64.

HSUEH PW, MCCLINTOCK JB AND HopkINS TS. 1993. Population Dynamics and Life History Characteristics of the Blue Crabs Callinectes similis and C. sapidus in Bay Environments of the Northern Gulf of Mexico. Mar Ecol 14: 239-257.

MACEDO SJ AND KoENING ML. 1987. Áreas estuarinas do estado de Pernambuco. Recife: CPRH, 350 p.

Macedo SJ, LiRA MEF AND Silva JE. 1973. Condições hidrológicas do Canal de Santa Cruz. Bol Rec Nat 11: 55-92.

MACEdo SJ, MonTES MJF AND LINS IC. 2000. Características abióticas da área estuarina do Canal de Santa Cruz. In: BARROS H ET AL. (Eds), Gerenciamento Participativo de Estuários e Manguezais, Recife: Editora Universitária, Recife, Brasil, p. 07-25.

MANTElatto FLM. 1995. Biologia reprodutiva de Callinectes ornatus Ordway, 1863 (Decapoda, Brachyura, Portunidae) na região de Ubatuba (SP), Brasil. Ph.D. thesis, Universidade Estadual Paulista, Brasil.

Mantelatto FLM And Fransozo A. 1996. Size at sexual maturity in Callinectes ornatus (Brachyura, Portunidae) from the Ubatuba region (SP) Brazil. Nauplius 4: 29-38.

NegreIros-FransOzo ML AND FransOzo A. 1995. On the distributional of Callinectes ornatus Ordway, 1863 and Callinectes danae Smith, 1869 (Brachyura, Portunidae) in the Fortaleza bay, Ubatuba, SP, Brazil. Iher Ser Zool 79: $13-25$.

NEGREIROS-FrANSOZO ML AND NAKAGAKI JM. 1998. Differential benthic occupation by crabs in the Ubatuba Bay, São Paulo, Brazil. J Shellfish Res 17: 293-297.

NETTO AS AND LANAPC. 1994. Effects of sediment disturbance on the structure of benthic fauna in a subtropical tidal creek of southeastern Brazil. Mar Ecol Prog Ser 106: 239-247. 
NORO CK AND BUCKUP L. 2008. Estrutura populacional e biologia reprodutiva de Parastacus defossus (Crustacea: Decapoda: Parastacidae). Rev Bras Zool 25: 624-629.

PAIVA ACG, COELho PA AND TORRES MFA. 2005. Influência dos fatores abióticos sobre a macrofauna de substratos inconsolidados da zona entre-marés no Canal de Santa Cruz, Pernambuco, Brasil. Arq Cienc do Mar 38: 85-92.

PEREIRA-BARRos JB AND TRAVASSOS IB. 1972. Informes sobre a pesca e a biologia do siri tinga (Callinectes danae) e gurjaú (Callinectes bocourti), na Lagoa Mundaú-Maceió - Alagoas. Recife: SUDENE/DRN RP, 7 p.

PINHEIRO MAA AND Fransozo A. 1998. Sexual maturity of the speckled swimming crab Arenaeus cribrarius (Lamark, 1818) (Crustacea, Brachyura, Portunidae), in Ubatuba littoral, São Paulo State, Brazil. Crustac Int J Crustac Res 71: 434-452.

Pita JB, Rodrigues ES, Lopes G ANd Coelho JAP. 1985. Observações bioecológicas sobre o siri Callinectes danae Smith, 1869 (Crustacea, Portunidae), no Complexo baíaestuário de Santos, Estado de São Paulo, Brasil. Bol Inst Pesca 12: 35-43.
Silva AMC, MANSO VAV AND NEUMANN VH. 2007. Shortterm changes and longshore transport on a steep fine sand beach: the example of the Itamaracá island,

NE Brazil. Est Geol 17: 71-84.

SILVA IG AND KoENING ML. 1993. Variação sazonal da densidade fitoplanctônica no estuário do Rio Paripe (Itamaracá PE). Arq Biol Tecnol 36: 645-658.

SoARES-Gomes A AND FIGUEIREDO AG. 2002. O Ambiente marinho. In: PEREIRA RC AND SOARES-GOMES A (Eds), Biologia Marinha, Rio de Janeiro: Interciência, Rio de Janeiro, Brasil, p. 1-33.

STRICKLAND JDH AND PARSONS TR. 1960. A manual of sea water analisys. Bull Fish Res Board Can 125: 1-185.

UNESCO. 1973. International oceanographic tables. National Institute of Oceanography of Great Britain, Wormley, and United Nations Educational, Scientific and Cultural Organization (UNESCO), Paris, France, 141 p.

WiLliams AB. 1974. The swimming crabs of the genus Callinectes (Decapoda, Portunidae). Fish Bull 72: 685- 798. 